American Journal of Applied Sciences 7 (2): 191-200, 2010

ISSN 1546-9239

(C) 2010 Science Publications

\title{
Study on the Key Success Factors of the Operation of a Regional Military Logistic Food Material Center
}

\author{
${ }^{1}$ Fu-Jin Wang, ${ }^{2}$ Chich-Jen Shieh and ${ }^{3}$ Chin-Jing Li \\ ${ }^{1}$ Department of Tourism, Aletheia University, \\ 32, Chen-Li Street, Tamsui Town, Taipei 25103, Taiwan, ROC \\ ${ }^{2}$ Department of International Business, Chang Chung Christian University \\ 396, Chang Jung Rd., Sec 1, Kway Jen, Tainan 71101, Taiwan, ROC \\ ${ }^{3}$ Department of Nursing, Mackay Medicine, Nursing and Management College, \\ No.92, Shengjing Rd., Beitou District, Taipei City 112, Taiwan, ROC
}

\begin{abstract}
Problem statement: In order to establish an integrated supply system of the military food material, the study was to discuss the key success factors of operation of the military regional food material logistic center in Taiwan. Approach: The Delphi method, questionnaires and telephone interviews were used to collect and integrate the opinions of experts and scholars. Simultaneously, the Analytic Hierarchy Process (AHP) was applied to confirm the evaluative factors of each level, i.e., one goal (to construct key success factors of the operation of a regional military logistic food material center) for the first level, two analytical aspects (the external and internal environments) for the second level, six evaluative facets (the safety design, strategic management, administrative effect, policy, service and internal and external integration) for the third level and 19 evaluative criteria for the fourth level. Results: The 350 questionnaires from the second phase which were sent out to four kinds of respondents, 319 valid ones were returned. Conclusion: After AHP analysis, the results of this study could suggest an evaluation table for the key success factors of operation of the military regional food material logistic center in Taiwan.
\end{abstract}

Key words: Food material logistic center, Delphi method, Analytic Hierarchy Process (AHP), Key Success Factors (KSF), military

\section{INTRODUCTION}

Research background: After implementing manpower-downsizing "Military Downsizing Policy" in recent years, the Taiwan Army needed a set of modernized, rapid and accurate logistics support plans to achieve the basic objectives of "war prevention", "homeland defense" and "counter-terrorism and contingency response". Meal service plan is a logistics support that is absolutely necessary to keep military power at a premium, but food material is a necessary consumable item which needs to be transported by way of freezing and refrigeration everyday. In order to avoid deficiency and take full advantage of food material, it must integrate the food suppliers and supply information upstream to meet the demands of all divisions of troops for different food and then use the existing human resources, sites and transport units to provide military officers and soldiers with cheap, fresh, diverse, safe, sanctified range of high-quality foods. Thus, it is urgent for the Taiwan Army to modernize and implement a high-quality regional military logistic food material center (Liu, 2005).

Working contents are used to measure logistics, in the form of order processing, inventory management, goods combination to that of distribution plan, are the equivalent to those of army's logistic supply. If by applying food logistics concepts, operation modes and key successful management factors of those used in the private sector to the meal requirements of a regional military logistic food material center, it can rapidly compensate for the operation loss of existing army's meal logistics (Coulter and Coulter, 2002).

In this study, key success factors of private enterprises' food material logistic centers were introduced into the Taiwan Army's routine food supply chain of the logistics of the military consumed foodstuff besides that of staple food. By taking the troops based

Corresponding Author: Chich-Jen Shieh, Department of International Business, Chang Chung Christian University 396,

Chang Jung Rd., Sec 1, Kway Jen, Tainan 71101, Taiwan, ROC

Tel: 886-6-2785-123/Ext. 2157 Fax: 886-6-2785-662 
in the northern area of Taiwan as the research object, key success factors of a regional military logistic food material center were investigated and discussed.

Research purpose: At present, the Taiwan Army takes the method of stations of the military consumed foodstuff besides that of staple food to offer food materials to its basic units. Each of which must be dispatched by specially-assigned personnel and a vehicle to each station to purchase the food materials required. By this way, it will incur a waste in human and material resources, but also be easy to delay food supply due to the breakdown of a vehicle or an unexpected personal injury in the course of transportation. Therefore, there can be no delay in establishing-a regional military logistic food material center.

However, there are few researches on the construction and operation of a regional military logistic food material center. Thus, the study used the Delphi Method and Analytic Hierarchy Process (AHP) to construct not only layers of key success factors affecting the operation of a regional military logistic food material center, but also a set of key factors affecting its operation. The results of these studies were expected to be helpful in both the theoretical development and practice.

\section{Literature review:}

Logistics and logistic center: The Council of Logistics Management (1988) defined logistics as referring to the process of a highly effective circulation and storage from the origin to the end users, which aims to meet the requirements of the customers. Ballou (1998) said that logistics focus on the activities of transportation and keeping goods in storehouse, which both include physical supply and physical distribution. The former covers the management of the acquiring and supplying of raw materials as well as that of semi-finished goods in stock to offer a flowing manufacture process. The latter refers to all activities of distributing products to customers which embrace order fulfillment, packing, stock control, warehousing, delivery and customer services and so on.

In a narrow sense, logistics indicates the physical movement from the supplier to the end user, which creates effectiveness in both location and time management. In a broad sense, logistics comprises of a series of value-creating processes from exploiting and acquiring resources all the way to the end users. In brief, it is a consolidation activity of products by which to satisfy at last the customers' needs.
A logistic center is connected by the flow of movement in the forms of physical, informative information, money and control. Different types of distribution centers have their own specific orientation and therefore, their functions are also varied. Fundamentally, the function of distribution centers can be summarized into the following five categories: (a) harmonizing supply and demand, (b) carrying out selling and marketing, (c) offering circulation of manufacture, (d) offering information and (e) resolving the conflicts between distribution channels (Schwarz et al., 1987; Bardi et al., 1993; Marien, 2000; Tan, 2001; Murphy and Poist, 2000; Cheng, 2003).

A logistic center is critical in the role of process of supply chain or in the distribution process of physical items. Its operational quality and efficiency influences largely the beneficial results of the supply chain. Logistics industry is recognized as a hard, filthy and dangerous service industry. Most of the logistic corporations in Taiwan are located in the layer of labor power; only a few belong to the layers of rationalization and automation. In this respect, the managers of logistic corporations in Taiwan have to endeavor to incorporate both automation and electronic information into the business operation so as to improve the operation processes, to curtail time of operation and promote stock accuracy and efficiency. The Development of the Radio Frequency Identification (RFID) technology has progressed rapidly in recent years and its application in various industries has become more mature. It can be expected that the application of the RFID technology will promote the operational efficiency of a logistics center, increase the accuracy of stock information, acquire customers' extended reliance, raise operating income and reach the goal of projects (Ryan, 2002).

The operation system of Taiwan military regional food material logistic centers is shown in Fig. 1. Under the current budget for Taiwan troops, if low-priced, high-quality, fresh, diversified, hygiene and safe food materials are to be expected, it is necessary to integrate both the supply information and capacity of suppliers with the requirements of all classes of troops for various food materials. This integration will make use of existing human resource, locations and transportation to build a modern operation system of a regional military logistic food material center.

Definition of Key Success Factors (KSF, or Critical Success Factors, CSF): The management level of most corporations uses key success factors to determine the direction and identify the goals to which their information systems are devoted. Daniel (1961) pointed out that KSF refer to the jobs that a company has to get done for survival. KSF are variables which vary with industries. 
Am. J. Applied Sci., 7 (2): 191-200, 2010

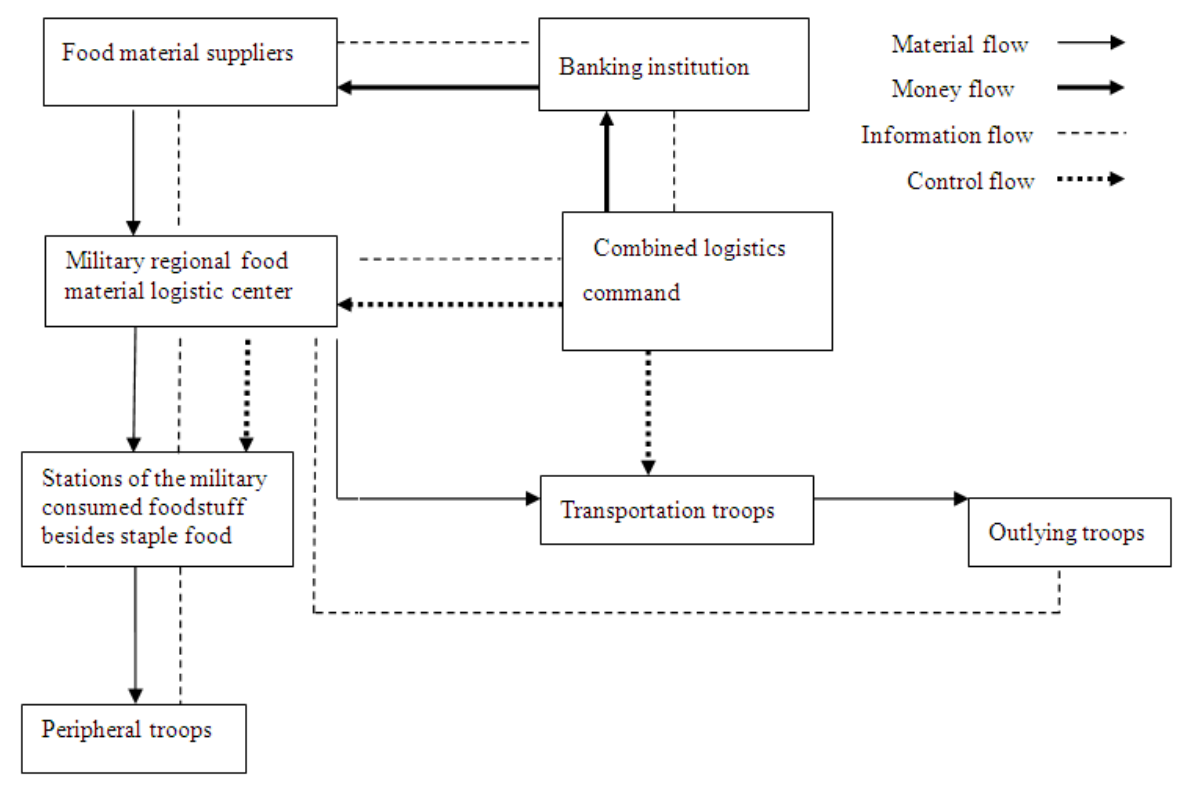

Fig. 1: The operation system of Taiwan military regional food material logistic centers

The strategies made under these variables affect exactly the whole competitive status of a company in an industry (Hofer and Schendle, 1987). Gammelgaard and Larson (2001) stated that only when a corporation can keep positive differentials of critical functions from its competitors, augment actual strength in KSF and develop competitive strategies based on KSF, can it secure its competitive edge. KSF are the source of sustainable competitive advantages and the most important competence or assets for a successful corporation. In other words, the durable competitive advantages of a corporation can be set up only when it seizes effectively KSF in a certain industry (Aaker, 1984). A corporation has to review its own conditions and resources with which to further design the strategies that are not easily simulated and followed by the competitors (Barney, 1997).

As discussed above, KSF are dynamics which will vary with business, time and region. They are the competence, resources and conditions possessed by a corporation for acquiring a competitive superiority. They urge a corporation to locate limited resources in the field of relevant competition for them to establish a superiority status (Gomez, 2000; Kotler, 1999).

Hierarchic structure of key success factors: Shank et al. (1985) stated that the analytical aspect of KSF can be explained by internal and external environments. The internal environment is composed of three facets, such as organizational personnel, organizational function and management and organizational structure and control. The external environment comprises of five facets, such as suppliers, competitors, social and political environment, technology and customers. Through the combination of AHP and the environments addressed by Shank et al. (1985) regarding KSF, the study tried to list the preliminary hierarchic structure of key success factors of the operation of a regional military logistic food material center, as shown in Table 1.

Because of different corporations and research topics, modification is usually necessary for the classification process above Level 3 (Table 1). For example, the study on the key success factors of the operation of a military regional food material logistic center is an obvious example which needs modification on the classification of its hierarchic structure. This kind of logistic center is a state-owned and has no competitors. Therefore, the facet "Competitors" in Layer 3 showed is not a suitable attribute for this case and had to be deleted.

According to the goal of a successful operation of a regional military food material logistic center, analytical aspects of key success factors could be divided into two categories-internal environment and external environment. Likewise, the internal environment originally covered organizational personnel, organizational function and management, as well as organizational structure and control whilst the external environment was modified to include four facets, such as suppliers, social and political environment, technology and customers. 
Am. J. Applied Sci., 7 (2): 191-200, 2010

Table 1: Preliminary hierarchic structure for key success factors of the operation of a military regional food material logistic center by an analytic hierarchy process

\begin{tabular}{|c|c|c|c|}
\hline Layer 1 (Goal) & $\begin{array}{l}\text { Layer } 2 \\
\text { (Analytical aspects) }\end{array}$ & $\begin{array}{l}\text { Layer } 3 \\
\text { (Evaluative facets) }\end{array}$ & $\begin{array}{l}\text { Layer } 4 \\
\text { (Evaluative criteria) }\end{array}$ \\
\hline \multirow{2}{*}{$\begin{array}{l}\text { To construct the key success } \\
\text { factors of the operation of a } \\
\text { military regional food material } \\
\text { logistic center }\end{array}$} & Internal environment & $\begin{array}{l}\text { Organizational personnel } \\
\text { Organizational function and management } \\
\text { Organizational structure and control }\end{array}$ & $\begin{array}{l}\text { Each facet of level } 3 \text { has its own } \\
\text { corresponding evaluative criteria }\end{array}$ \\
\hline & External environment & $\begin{array}{l}\text { Suppliers } \\
\text { Competitors } \\
\text { Social and political environment } \\
\text { Technology } \\
\text { Customers }\end{array}$ & \\
\hline
\end{tabular}

The study adopted the Delphi method to reach common consensus of experts and scholars and then generalized three new facets--safety design, strategic management and administrative effect--to represent the original three facets of the internal environment. At the same time, another three new facets--policy, service and internal and external integration--are summarized to represent the original four facets of the external environment for further analysis as discussed below.

\section{MATERIALS AND METHODS}

Delphi method: Fowles (1978) asserts that the word Delphi refers to the hallowed site of the most revered oracle in ancient Greece. Forecasts and advices from gods were sought through intermediaries at this oracle. However, Dalkey (1968a) states that the name "Delphi" was never a term with which either Helmer or Dalkey (the founders of the method) were particularly happy. Dalkey (1968b) acknowledged that it was rather unfortunate that the set of procedures developed at the RAND Corporation and designed to improve methods of forecasting came to be known as "Delphi". He argued that the term implies "something oracular, something smacking a little of the occult", whereas, as a matter of fact, precisely the opposite is involved; it is primarily concerned with making the best you can of a less than perfect information. The objective of most Delphi applications is the reliable and creative exploration of ideas or the production of suitable information for decision making. The Delphi Method is based on a structured process for collecting and distilling knowledge from a group of experts by means of a series of questionnaires interspersed with controlled opinion feedback (Adler and Ziglio, 1995). Martino (1983) listed major concerns about the Delphi method:

- Discounting the future: Future (and past) happenings are not as important as the current ones; therefore one may have a tendency to discount the future events

- The simplification urge: Experts tend to judge the future of events in isolation from other developments. A holistic view of future events where change has had a pervasive influence cannot be visualized easily. At this point, cross-impact analysis is of some help

- Illusory expertise: Some of the experts may be poor forecasters. The expert tends to be a specialist and thus views the forecast in a setting which is not the most appropriate one

- Sloppy execution: There are many ways to do a poor job. Execution of the Delphi process easily may result in the loss of attention required

- Format bias: It should be recognized that the format of the questionnaire may be unsuitable to some potential societal participants

- Manipulation of Delphi: The responses can be altered by the monitors in the hope of moving the next round of responses in a desired direction

Analytical Hierarchy Process (AHP): The Analytical Hierarchy Process Model was first developed in the 1970 by Saaty (1980) as a decision making aid. AHP is especially suitable for complex decisions which involve the comparison of elements which are difficult to quantify. It is based on the assumption that when faced with a complex decision the natural human reaction is to cluster the elements together according to their common characteristics. It involves building a hierarchy (ranking) of decision elements and then making comparisons between each possible pairing in each cluster (as a matrix). This gives a weighting for each element within a cluster (or level of the hierarchy) and is also a consistency ratio (useful for checking the consistency of the data). The main purpose of AHP is to assist in decision-makers to dissect logically and smoothly complicated problems and further solve problems when they are faced with a situation of 
complexity and difference (Saaty, 1980; 1990; Saaty and Vargas, 1981).

Research framework: Two-phase questionnaires were adopted in the study to investigate the evaluation model of key success factors of the operation of a regional military logistic food material center.

Questionnaire of the first phase: Documentation and literature regarding the weaknesses of services of military food within material supply were examined and then the opinions of barrack senior officials of different levels and those of officials who were in charge of the meals services were collected through interviews. Based on the data collected, the questionnaire of the first phase was designed to investigate the analytical aspects, evaluative facets or dimension and evaluative criteria of key success factors of the operation of a regional military food material logistic center.

The questionnaire of the first phase was to set up the preliminary evaluative facets and criteria of key success factors of the operation of a regional military logistic food material center. A total of 50 questionnaires were sent out and 48 were returned (a rate of $96 \%)$.

After an invalid questionnaire was removed, the remaining 47 questionnaires were used to carry out the analysis on individual fundamental data, such as gender, age, branches of the armed forces, professional, rank, education, seniority. If or if not devoted to relative jobs of logistics or meals supply and if they where satisfied with the services offered by suppliers of military food material. The modified preliminary hierarchic structure of key success factors of the operation of a regional military logistic food material center where then generated from the results of the questionnaire survey of the first phase, which contained one goal, two analytical aspects, six evaluative facets and 35 evaluative criteria.

Questionnaire of the second phase: The evaluation results from the questionnaire of the first phase were delivered to the experts and scholars (middle/high class commissioned officers of military logistics and teachers of College of Management, National Defense University) for further discussions carried out under the Delphi method. The discussions were to minimize the divergences of opinions of the experts and scholars to reach a common consensus on how to increase or reduce the evaluative facets (level 3 ) and the evaluative criteria (level 4) of the hierarchic structure derived from AHP (Linstone and Turoff, 1975) for key success factors of the operation of a regional military logistic food material center. In other words, the hierarchic structure of key success factors was finally established and the design of the questionnaire of the second phase (i.e., the formal AHP questionnaire for this study) was completed.

After the literature review and detailed discussions among experts and scholars, the hierarchic structure for key success factors was confirmed. The structure concluded one goal for level 1, two analytical aspects (internal environment and external environment) for level 2, six evaluative facets (safety design, strategic management and administrative effect; policy, service and internal and external integration) for level 3 and 19 evaluative criteria for level 4. For the internal environment aspect, safety design facet refers to the planning and safety control of confidential military secrets and internet information systems; strategic management facet refers to focusing on the orientation of both the improvement of food material supply and cost efficiency; whilst the administrative effect facet refers to focusing on organizational reform and professional orientation. For the external environment aspect, policy facet indicates government's production and marketing policy and laws and regulations of agriculture and food; service facet indicates customer orientation and relation management; internal and external integration facet indicates strategic alliances and cooperation. Detailed descriptions of the confirmed hierarchic structure of key success factors are shown in Table 2.

The questionnaire for the second phase was sent to the above experts and scholars for confirmation and then 350 questionnaires were delivered to four kinds of respondents: (a) officers and men of troops in the receiving supply chain (those in charge of catering purchase and meals service), (b) government institutions in charge of supervising the supply of the military consumed foodstuff besides staple food, (c) suppliers of the military consumed foodstuff besides staple food and (d) experts and scholars.

The background of the above respondents was analyzed to confirm that they were a representative sample. AHP was then applied to measure the relative weight of each factor (aspect, facet and criterion) and detect a consensus of the relative weight. Finally, the study integrated the evaluation results of AHP to address the suggestions for key success factors of the operation of a regional military logistic food material center.

Questionnaire survey and collection of the second phase: Of 350 questionnaires from the second phase which were sent out to four kinds of respondents above, 319 valid ones were returned. An analysis of the returned provided the following data: 
Am. J. Applied Sci., 7 (2): 191-200, 2010

Table 2: Results of analysis on the key success factors of the operation of a military regional food material logistic center by an analytic hierarchy process

\begin{tabular}{|c|c|c|c|c|}
\hline Layer 1 (Goal) & $\begin{array}{l}\text { Layer } 2 \\
\text { (Analytical aspects) }\end{array}$ & $\begin{array}{l}\text { Layer } 3 \\
\text { (Evaluative facets) }\end{array}$ & $\begin{array}{l}\text { Layer } 4 \\
\text { (Evaluative criteria) }\end{array}$ & \\
\hline \multirow[t]{19}{*}{$\begin{array}{l}\text { To construct the key success } \\
\text { factors of the operation of } \\
\text { a military regional food } \\
\text { material logistic center }\end{array}$} & $\begin{array}{l}\text { Internal environment } \\
74.55^{\mathrm{a} *}\end{array}$ & $\begin{array}{l}\text { Safety design (the planning } \\
\text { and safety control of confidential } \\
\text { military secrets and internet } \\
\text { information systems) } 34.46^{\mathrm{a}}\end{array}$ & $\begin{array}{l}\text { To expand and integrate the existing internal } \\
\text { information system and simultaneously to } \\
\text { assure to keep the internet information system } \\
\text { confidential and safe }\end{array}$ & $16.27^{\mathrm{a}}$ \\
\hline & & & $\begin{array}{l}\text { To draw up a perfect information platform for the } \\
\text { supply chain of logistics and to build a portal site of } \\
\text { food material of the supply chain }\end{array}$ & $13.91^{\mathrm{b}}$ \\
\hline & & & $\begin{array}{l}\text { To establish the test standard of toxicity for hygiene } \\
\text { quality of food material }\end{array}$ & $4.28^{g}$ \\
\hline & & $\begin{array}{l}\text { Strategic management (focusing on } \\
\text { the orientation of both the improvement }\end{array}$ & $\begin{array}{l}\text { To set up the E-management strategy of application } \\
\text { for supply }\end{array}$ & $3.16^{\mathrm{h}}$ \\
\hline & & of cost efficiency) $20.27^{\mathrm{b}}$ & $\begin{array}{l}\text { To draw up the management system supply and } \\
\text { strengthen communication of the operation } \\
\text { mechanism of coordination }\end{array}$ & $10.89^{c}$ \\
\hline & & & $\begin{array}{l}\text { To set up an evaluation to reduce the purchase cost } \\
\text { and increase added value }\end{array}$ & $6.32^{\mathrm{e}}$ \\
\hline & & $\begin{array}{l}\text { Administrative effect (focusing on } \\
\text { organizational reform and } \\
\text { professional orientation) } 19.82^{b}\end{array}$ & $\begin{array}{l}\text { To foster professionals of logistics management of } \\
\text { food material and promote skills and efficiency of } \\
\text { implementation }\end{array}$ & $5.25^{\mathrm{g}}$ \\
\hline & & & $\begin{array}{l}\text { To draw up groups of consultants, introduce } \\
\text { successful experiences and the practices of food } \\
\text { material logistics }\end{array}$ & $3.30^{\mathrm{i}}$ \\
\hline & & & $\begin{array}{l}\text { To set up a whole set of performance evaluation } \\
\text { and standards to cut operational drop }\end{array}$ & $4.01^{\mathrm{h}}$ \\
\hline & & & $\begin{array}{l}\text { To construct a mechanism of dealing with } \\
\text { contingency for keeping operational efficiency } \\
\text { when located in war }\end{array}$ & $7.26^{\mathrm{d}}$ \\
\hline & $\begin{array}{l}\text { External environment } \\
25.45^{\mathrm{b}}\end{array}$ & $\begin{array}{l}\text { Policy (government's production } \\
\text { and marketing policy and laws } \\
\text { and regulations of agriculture } \\
\text { and food) } 9.30^{c}\end{array}$ & $\begin{array}{l}\text { To operate in coordination with the establishment of } \\
\text { military food material logistic center and amend } \\
\text { untimely laws and decrees regarding the } \\
\text { management of agriculture and food }\end{array}$ & $1.13^{\mathrm{k}}$ \\
\hline & & & $\begin{array}{l}\text { To map out the system of E-application for the } \\
\text { supply of food material logistics and the } \\
\text { relative information platform }\end{array}$ & $7.13^{\mathrm{d}}$ \\
\hline & & & $\begin{array}{l}\text { To open up the information about the supply chain } \\
\text { of the food material and to connect with the civilian } \\
\text { related businesses }\end{array}$ & $1.04^{\mathrm{k}}$ \\
\hline & & Service (customer orientation and & To promote the users' satisfaction & $2.10^{\mathrm{j}}$ \\
\hline & & relation management) $4.16^{\mathrm{d}}$ & $\begin{array}{l}\text { To draw up a channel of interaction between the user } \\
\text { and the supplier }\end{array}$ & $1.05^{\mathrm{k}}$ \\
\hline & & & $\begin{array}{l}\text { To respond accurately and quickly to the } \\
\text { requirements of the users and suppliers }\end{array}$ & $1.01^{\mathrm{k}}$ \\
\hline & & $\begin{array}{l}\text { Internal and external integration } \\
\text { (strategic alliances and cooperation) } \\
11.99^{\mathrm{c}}\end{array}$ & $\begin{array}{l}\text { To attach importance to the development and } \\
\text { maintenance of the program of information system } \\
\text { and the transfer of the relative technology }\end{array}$ & $3.40^{\mathrm{h}}$ \\
\hline & & & $\begin{array}{l}\text { To draw up a purchase mechanism and united } \\
\text { contracts for the supply of food material }\end{array}$ & $2.71^{\mathrm{i}}$ \\
\hline & & & $\begin{array}{l}\text { To program the location of setting up and the } \\
\text { routes for a united delivery and supply chain }\end{array}$ & $5.88^{f}$ \\
\hline
\end{tabular}

Of the 284 questionnaires sent to officers and men of troops in the receiving supply chain (those in charge of catering purchase and meals service), 254 valid ones were returned (rate of $254 / 284=89.43 \%$; if compared with the total valid of 319 , rate of $254 / 319=79.62 \%$ ).

Of the 15 questionnaires sent to government institutions in charge of supervising supply of the military consumed foodstuff besides staple food, 15 valid ones were returned (rate of $15 / 15=100.00 \%$; if compared with the total valid of 319 , rate of $15 / 319=4.70 \%$ ).

Of the 26 questionnaires sent to suppliers of the military consumed foodstuff besides staple food, 26 valid ones were returned (rate of 26/16 = $100.00 \%$; if compared with the total valid of 319 , rate of $26 / 319=8.15 \%$ ).
Of the 24 questionnaires sent to experts and scholars, 24 valid ones were returned (rate of $24 / 24=100.00 \%$; if compared with the total valid of 319 , rate of $24 / 319=7.52 \%$ ).

Statistical calculation: Calculations on discussions generated from the Delphi method were carried out by the visual basic application of Excel 97 to facilitate index collection. Expert Choice 2000 was applied to carry out the structure analysis of AHP for the relative weight of each factor. Then, the consistence of the relative weight of each factor was further confirmed with the index of Consistency Ratio (CR) $<0.1$ and Consistency Ratio of Hierarchy $(\mathrm{CRH})<0.1$. The 
Duncan's multiple range test was used to analyze the differences among data SAS program: (Duncan, 1955).

\section{RESULTS}

With AHP to analyze the data collected from the questionnaire survey of the second phase, it was found that the Relative Weight (RW) of each aspect (level 2) was internal environment (74.55\%) and external environment (25.45\%). The relative weights of facets (level 3) under internal environment were safety design (34.46\%), strategic management (20.27\%), administrative effect (19.82\%); those under external environment were policy (9.30\%), service $(4.16 \%)$ and internal and external integration (11.99\%). Further discussions were addressed below.

Safety design $(\mathrm{RW}=\mathbf{3 4 . 4 6 \%})$ : Three evaluative criteria's where included under safety design and their relative weights were "To expand and integrate the existing internal information system and simultaneously to assure to keep the internet information system confidential and safe”(16.27\%),"To draw up a perfect information platform for the supply chain of logistics and to build a portal site of food material of the supply chain" (13.91\%) and "to establish the test standard of toxicity for hygiene quality of food material” (4.28\%).

Strategic management $(\mathrm{RW}=\mathbf{2 0 . 2 7 \%})$ : Three evaluative criteria's where included under strategic management and their relative weights were "To set up the E-management strategy of application for supply" (3.16\%), "To draw up the management system and database of application for supply and strengthen communication of the operation mechanism of coordination" (10.89\%) and "To set up an evaluation to reduce the purchase cost and increase added value" (6.32\%).

Administrative effect $(\mathrm{RW}=19.82 \%)$ : Four evaluative criteria's where included under administrative effect and their relative weights were "To foster professionals of logistics management of food material and promote skills and efficiency of implementation" (5.25\%), "To draw up groups of consultants, introduce successful experiences and the practices of food material logistics" (3.30\%), "To set up a whole set of performance evaluation and standards to cut operational drop" (4.01\%) and "To construct a mechanism of dealing with contingency for keeping operational efficiency when located in war" (7.26\%).

Policy (RW $=9.30 \%)$ : Three evaluative criteria's where included under policy and their relative weights were "To operate in coordination with the establishment of military food material logistic center and amend untimely laws and decrees regarding the management of agriculture and food" (1.13\%), "To map out the system of E-application for supply of food material logistics and the relative information platform" (7.13\%) and "To open up the information about the supply chain of the food material and to connect with the civilian related businesses” (1.04\%).

Service (RW $=\mathbf{4 . 1 6 \%})$ : Three evaluative criteria's where included under service and their relative weights were "To promote the users' satisfaction" (2.10\%), "To draw up a channel of interaction between the user and the supplier" (1.05\%) and "To respond accurately and quickly to the requirements of the users and suppliers" (1.01\%).

Internal and external integration $(\mathrm{RW}=\mathbf{1 1 . 9 9 \%})$ : Three evaluative criteria's where included under internal and external integration and their relative weights were "To attach importance to the development and maintenance of the program of information system and the transfer of the relative technology" (3.40\%), "To draw up a purchase mechanism and united contracts for the supply of food material" (2.71\%) and "To program the location of setting up and the routes for a united delivery and supply chain” (5.88\%).

The results of the study can then be used to construct a series of indexes for evaluating the KSF of operation of a regional military logistic food material center. The study found that if troops focused on how to improve the operation of meals supply, as compared to the external environment, the internal environment is the principal aspect for them to consider in their decision-making. Of 19 evaluative criteria for level 4, "To expand and integrate the existing internal information system and simultaneously to assure to keep the internet information system confidential and safe", "To draw up a perfect information platform for the supply chain of logistics and to build a portal site of food material of the supply chain" and "To draw up the management system and database of the application for supply and strengthen communication of the operation mechanism of coordination" are the three most important evaluative criteria, as compared to the other 16.

\section{DISCUSSION}

Research contribution, future prospect and
suggestion: Improving the existing military meal supply operation and management mode to meet troops' requirements: The existing mode of military meal 
supply operation and management can be divided into the following two aspects:

- The army complies with army provisions (rice, flour and edible oil) of the operation system of military goods supply. Its application process, supply unit and management are quite similar to those of private enterprises' logistic centers (Gammelgaard and Larson, 2001). However, due to the vague processes of application, supply operation of army provisions and lack of good management mechanisms of warehouse storage (Liu, 2005). The overall information control on both allocating warehouses and supplied units, causes such cases as deterioration, dampness, addling and leakage occur and accordingly, leading to the waste of food materials.

- $\quad$ The army purchases all kinds of meal materials for the group meal units itself. Although there are established stations of the military consumed foodstuff besides staple food which are supervised and managed by Combined Logistics Command and regional army corps. Such factors as climate and season occur at the time of supply often resulting in prices, qualities and quantities that cannot meet the demands of the group meal units by the suppliers. Additionally, there are other factors such as uneven professional abilities of management and purchasing personnel, failure to effectively check qualities of the goods due to time factor and no related units to correctly offer information on sanitary and toxicity inspection for all food materials. The result of all these factors is that the demands of the army's group meal units cannot be promptly met and security of these units is threatened.

Taking management mechanism of corporate food material logistic center as an important mirror for military meal supply renovation: All military food supplies goals should be with a view to meeting the army's demands. In order to adapt to rapid change within the market, private enterprises need to successively introduce information and logistic management mechanism to integrate their resources, increase efficiency and obtain common benefits. The military meal supply service which was oriented at supporting and meeting the demands of army's combat readiness should place an emphasis on support flexibility, accuracy and speed as well as sanitary and quality of the food materials supplied (Andersson and Norrman, 2002). Therefore, the management mechanism of a corporate food material logistic center should be seen as an important mirror for military meal supply renovation.

Introducing management mechanism of logistic center to promptly reflect army's demands and upgrade service quality: The management mechanism of a logistic center is to put the product or service through the management mechanism of information system so as to create added value, realize economic, prompt, efficient and rapid logistics and meet clients' demands (Tan, 2001). Under “Client-oriented” service concept, suitable introduction of management mechanism of a logistic center into logistic management of the army can efficiently grasp the army's food demands and balance the nutrition of military members, upgrade service quality, realize the requirements that logistics supports army's combat adaptively and in the form of right-quality, rightquantity, right-time and right-place.

New prospect of meal logistic operation-immediate food material logistic response center: The existing meal supply operation of the army is based on batch and quantity management. Except for consuming enormous materials and human resources, it will greatly increase the operation load of grass-root troops, reduce the army's maneuverability and raise the army's nondeterminacy in the battlefields (Martino, 1983; Marien, 2000; Liu, 2005). Therefore, an operation mode named as "Immediate food material logistic response center" which is more rapid, reliable, accurate and economic than the present ones should be established, by which food materials required for reinforcement of army's fighting strength can be immediately delivered to clients (supplied units) when is necessary. In this way, it can immediately supply adaptive and secure food materials, eliminate unnecessary storage and waste, reduce risk as well as raise army's fighting strength and supply efficiency.

Realizing new prospect of immediate meal logistic operation and constructing regional military logistic food material response center: With the development of national defense science and technology and change of battle form, it is urgent to meet the demands of combat troops in order to adapt to constant-change battlefield situations. Only "immediate, accurate, reliable and economic" logistics techniques can meet the army's requirements (Hofer and Schendel, 1987; Murphy and Poist, 2000). The army should therefore switch from a traditional thinking mode to conduct organizational and operational adjustment for meal logistic supply, construct regional food material logistic center and introduce 
operation mode and management mechanism of corporate logistic center to enable all classes of troops to obtain high-quality, inexpensive, nutrition-balanced, good-taste and good-smell food materials and improve the meal supply efficiency and service quality.

\section{CONCLUSION}

This study has investigated the key success factors of operation of the military regional food material logistic center in Taiwan for controlling the risk management. The result of this study provides a simple, practical and valued method for to establish a complete the military regional food material logistic center. AHP has a excellent tool to make decision from complex and multiple factors and provides a quantitative analytic model.

\section{REFERENCES}

Aaker, D.A., 1984. Strategic Marketing Management. Wiley, New York, pp: 79.

Adler, M. and E. Ziglio, 1995. Gazing into the Oracle: The Delphi Method and its Application to Social Policy and Public Health. 1st Edn., Jessica Kingsley Publishers, London, ISBN: 10: 1853021040, pp: 252.

Andersson, D. and A. Norrman, 2002. Procurement of logistics services-a minutes work or a multi-year project. Eur. J. Purchas. Supply Manage., 8: 3-14.

Ballou, R.H., 1998. Business Logistics Management. 4th Edn., Prentice Hall, Upper Saddle River, NJ., ISBN: 10: 0137956592, pp: 696.

Bardi, E.J., J.J. Covel and Jr. C.J. Langiev, 1993. The Management of Business Logistics. 6th Edn., West Publishing Company, New York, pp: 158.

Barney, J.B., 1997. Gaining and Sustaining Competitive Advantage. 1st Edn., Addison-Wesley, Reading, MA, ISBN: 9780201512854, pp: 570.

Cheng, L.C., 2003. QFD in product development: Methodological characteristics and a guide for intervention. Int. J. Qual. Reliab. Manage., 20: 107-122.

Coulter, K.S. and R.A. Coulter, 2002. Determinants of trust in a service provider: The moderating role of length of relationship. J. Services Market., 16: 35-50.

Dalkey, N.C., 1968a. The Delphi Method: An Experimental Study of Group Opinions. 1st Edn., The RAND Corporation, Santa Monica CA., pp: 124-151.
Dalkey, N.C., 1968b. Predicting the Future. RAND Corporation, Santa Monica, CA., pp: 19

Daniel, R.D., 1961. Management information crisis. Harvard Bus. Rev., 39: 111-121.

Duncan, D.B., 1955. Multiple range and multiple F-test. Biochem. J., 11: 1-42.

Fowles, J., 1978. Handbook of Futures Research. 1st Edn., Greenwood Press, Westport, CT., pp: 822.

Gammelgaard, B. and P.D. Larson, 2001. Logistics skills and competences for supply chain management. J. Bus. Logist., 22: 27-50.

Gomez, J.D.L., 2000. Dynamic capabilities as a way to Compete: The Case of a Spanish Company. Proceeding of the International Telecommunications Society 13th Biennial Conference. Jan. 12-12, Buenos Aires, Argentina, pp: 33-46.

Hofer, C.W. and D. Schendel, 1987. Strategy Formulation: Analytical Concepts. 12th Edn., Harvard Business School Press, Boston, MA., ISBN 0829902139, pp: 219.

Kotler, P., 1999. Marketing Management: The Millennium Edition. 10th Edn., Prentice Hall, Upper Saddle River, NJ., ISBN: 10: 0130122173, pp: 784.

Linstone, H.A. and M. Turoff, 1975. The Delphi Method: Techniques and Applications. AddisonWesley, Boston, MA., pp: 620.

Liu, W.S., 2005. Study on management of military stuff supply-the army as example. Defense J., 20: 115-119.

Marien, E.J., 2000. The four supply chain enablers. Supply Chain Manage. Rev., 1: 60-68.

Martino, J.P., 1983. Technological Forecasting for Decision-Making. 2nd Edn., North-Holland, New York, ISBN-10: 0444007229 pp: 384.

Murphy, R.P. and F.R. Poist, 2000. Third-party logistics: Some user versus provider perspectives. J. Bus. Logist., 21: 121-133.

Ryan, M.R., 2002. A model for the Implementation of a radio frequency identification system into a warehouse environment. 1st Edn., MS Michigan State University, USA., pp: 234.

Saaty, T.L. and L.G. Vargas, 1981. The Logic of Priorities: Applications of Business, Energy, Health and Transportation. Springer, ISBN: 10: 0898380782, pp: 320.

Saaty, T.L., 1980. The Analytic Hierarchy Process. 2nd Edn., McGraw-Hill, New York, pp: 287.

Saaty, T.L., 1990. The Analytic Hierarchy Process. 2nd Edn., RWS Publications, Pittsburgh, PA., pp: 287.

Schwarz, L.B., S.C. Graves and W.H. Hausman, 1987. Scheduling policies for automatic warehousing system: Simulation results. AIIE Trans., 10: 260-270. 
Am. J. Applied Sci., 7 (2): 191-200, 2010

Shank, M.E., A.C. Boynton and R.W. Zmud, 1985. Tan, K.C., 2001. A framework of supply chain Critical success factor analysis as a methodology for MIS planning. MIS Q., 9: 121-130.

management literature. Eur. J. Purchas. Supply Manage., 7: 39-48. 